\title{
EFEKTIFITAS PEMBELAJARAN JARAK JAUH DALAM PERSPEKTIF HAK ASASI MANUSIA PADA MASA PANDEMI COVID-19 DI INDONESIA
}

\author{
Andi Sugistino Prayoga, Enjel Kostansa Waitau, Mahfudhotul Jannah, \\ Rahma Shavira Ardana, Fania Rachamaningrum. \\ Sekolah Tinggi Ilmu Kesehatan (STIKes) Surabaya \\ andyfergas21@gmail.com.waitauenjel@gmail.com. Fudlojannah@gmail.com. \\ rahmaardana99@gmail.com.
}

\begin{abstract}
The implementation of distance education in various schools ranging from elementary, secondary, upper and up to college has raised a variety of new problems that the government itself is ready to accumulate rights in all matters especially in education. along with the development of existing technology in Indonesia today, has notnal the distance education system that has been regulated by the government. Thus, the distance education system becomes an alternative when students or students cannot face-to-face in the school or campus environment. The purpose of this writing is to find out how big the level of quality and anticipation in the effectiveness of distance learning in Indonesia who and what feed back has been obtained by the palajar during the covid-19 pandemic in Indonesia. This research is a type of qualitative research. Qualitative research is a method to find data that is then collected and is understanding and can not be measured by numbers, prioritizing the depth of understanding of interactions between concepts that are being studied imperis. So that qualitative research results are inseparable from the subjectivity of researchers. As stated by Semiawan that the results of commulitative research are strongly influenced by the views, thoughts and knowledge of researchers. The results of this study revealed that distance education in Indonesia has not been as effective. therefore in this study we as researchers hope that this writing can be implemented by the government so that the community, especially students who apply online or online methods can be met and run effectively in accordance with Operational Standards Procedures (SOP)
\end{abstract}

Keywords: effectiveness of education; distance learning; Ham. 


\begin{abstract}
ABSTRAK
Pelaksanaan pendidikan jarak di berbagai sekolah mulai dari tingkat dasar, menengah, atas dan sampai perguruan tinggi telah menimbulkan berbagai masalah baru yang pemerintah sendiri itu belom siap dalam mengakumulasi hak-hak dalam semua hal terutama dalam pendidikan. seiring dengan perkembangan teknologi yang ada di Indonesia saat ini, belum menganal system pendidikan jarak jauh yang sudah di atur oleh pemerintah. Dengan demikian system pendidikan jarak jauh menjadi alternatif ketika siswa ataupun mahasiswa tidak bisa tatap muka secara langsung di dalam lingkungan sekolah ataupun kampus. Tujuan penulisan ini adalh untuk mengetahui seberapa besar tingkat kualitas dan kuantias dalam keefektifan pembelajaran jarak jauh di Indonesia siapa dan apa feed back yang telah didapatkan oleh para palajar pada masa pandemi covid-19 di Indonesia ini. Penelitian ini merupakan jenis penelitian kualitatif. Penelitian kualitatif merupakan metode untuk mencari data yang kemudian dikumpulkan dan bersifat pemahaman serta tak bisa di ukur dengan angka, mengutamakan kedalaman penghayatan terhadap interaksi antar konsep yang sedang dikaji secara imperis. Sehingga hasil penelitian kualitatif tidak terlepas dari subjektivitas peneliti. Sebagai mana yang dikemukakan oleh Semiawan bahwa hasil penelitian komulitatif sangat di pengaruhi oleh pandangan,pemikiran dan pengetahuan peneliti. Hasil penelitian ini mengungkapkan bahwa pendidikan jarak jauh di indonesia telah kurange fektif oleh karena itu dalam penelitian ini kami sebagai peneliti berharap penulisan ini bisa di implementasikan oleh pemerintah agar masyarakat khususnya para pelajar yang menerapkan metode daring atau online bisa terpenuhi dan berjalan dengan efektif sesuai Standar Operasional Prosedur (SOP).
\end{abstract}

Kata kunci : Efektivitas Pendidikan; Pembelajaran Jarak Jauh; HAM. 


\section{PENDAHULUAN}

Sebagai warga negara Indonesia kita mempunyai beberapa kewajiban, salah satunya kewajibam umtuk mendapatkan pendidikan yang selayaknya, di Indonesia kebanyakan masyarakatnya belum sepenuhnya menerima pendidikan, salah satunya contoh msyarakat yang tinggal di desa yang terpencil. Ini bukan karena faktor masyarakatnya akan tetapi faktor utamannya berasal dari pemerintahan itu sendiri. Dimana mereka hanya memantau daerah perkotaan.

Pelaksanaan pendidikan jarak di berbagai sekolah mulai dari tingkat dasar, menengah, atas dan sampai perguruan tinggi telah menimbulkan berbagai masalah baru yang pemerintah sendiri itu belom siap dalam mengakumulasi hakhak dalam semua hal terutama dalam pendidikan. seiring dengan perkembangan teknologi yang ada di Indonesia saat ini, belum menganal system pendidikan jarak jauh yang sudah di atur oleh pemerintah. Dengan demikian system pendidikan jarak jauh menjadi alternatif ketika siswa ataupun mahasiswa tidak bisa tatap muka secara langsung di dalam lingkungan sekolah ataupun kampus.

Pendidikan jarak jauh (PJJ) ini dimulai sejak terjadinya wabah virus covid-19 yang menyebar di Indonesia pada bulan maret 2020 dimana system pendidikan pembelajaran jarak jauh yang sebelunya merupakan suatu pembelajaran alternatif yang sekarang menjadi suatu kewajiban yang harus dilakukan oleh sekolah atau instusi pendidikan yang di Indonesia di karenakan kebijakanpemerintah dalam mencegah penyebaran virus covid-19. UNESCO mengungkapkan bahwa banyak negara telah menutup sekolah untuk menghindari penyebaran covid-19 dikalangan pelajar yang berpotensi berdampak luas, ${ }^{1}$ dan hal ini dilakukan juga di Indonesia. Permasalahan ini selanjutnya menjadi focus penelitian dalam penulisan ini.

Terdapat referensi berupa penelitian terdahulu yang memiliki keterkaitan dengan penelitina ini. adapun penelitian terdahulu yang pernah dilakukan oleh para peneliti sebelumnya diantaranya yaitu berjudul "pendidikan jarak jauh" yang dilakukan oleh Area Jalil pada tahun 1994, yang memperlihatakan bahwa pendidikan jarak atau PJJ memberikan kesempatan untuk peningkatan mutu pendidikan yang sesuai dengan perkembangan iptek, namun dala penerapanya harus memperhataikan factor kesiapan antara semua pihak yang berkepentingan demi tercapainya efektivitas $\mathrm{PJJ}^{2}$. Kemudian terdapat penelitian mengenai efektifitas PJJ dalam artikel efektifitas pemebelajaran jarak jauh terhadap pemebelajaran siswa di SDIT dendektia purwakarta oleh Anggy Giri Prawiyogi et al pada mei 2020 yang berkesimpulan bahwa PJJ merupakan metode pembelajaran yang cukup efektif sebagai pengganti pemebelajaran dengan tatap muka dimasa pandemic covid-19, namun tetap memiliki kendala yang harus di hadapi, seperti permasalahan teknis, dimana ada listrik yang padam atau jaringan internet yang buruk, orang tua yang tidak mendampingi siswa, ataupun siswa yag tidak konsisten dengan jadwal belajar yang ditetukan. ${ }^{3}$

Dalam Universal Deklaration Off Human Rights, persamaan hak bagi setiap negara untuk memperoleh pengajaran/pendidikan ini dapat dijumpai pada pasal 26 ayat (1) ayat (2) yang menyatakan: (1) setiap orang berhak mendapat pendidikan. pendidikan harus gratis, setidak-tidaknya untuk tingkat sekolah dasar dan pendidikan dasar. Pendidikan dasar harus diwajibkan. Pendidikan teknik dan kejuruan harus tersedia secara umum, dan pengajaran tinggi harus secara adil dan di akses oleh semua orang, berdaarkan kepantasan. (2) pendidkan harus ditunjukkan kea rah perkembangan pribadi yang seluasluasnya serta memperkokoh rasa penghargaan terhadap hak-hak manusia dan kebebasan asasi. Pendidikan harus memepertingggi saling pengertian, toleransi, dan persahatan diantara semua bangsa, kelompk ras, maupun agama, 
serta harus memajukan kegiatan perserikatan bangsa-bangsa dalam memelihara perdamain. ${ }^{4}$

Berdasarkan pendahuluan permasalahan di atas, maka dapat di simpulkan beberapa rumusan masalah sebagai berikut :

1. Bagaimana penerapan system pendidikan jarak jauh pada masa pandemi di Indonesia?

2. Bagaimana hubungan pendidikan jarak jauh dengan hak asasi manusia pada masa pandemi di indonesia ?

\section{METODE PENELITIAN}

Penelitian ini merupakan jenis penelitian kualitatif. Penelitian kualitatif merupakan metode untuk mencari data yang kemudian dikumpulkan dan bersifat pemahaman serta tak bisa di ukur dengan angka, mengutamakan kedalaman penghayatan terhadap interaksi antar konsep yang sedang dikaji secara empiris. Sehingga hasil penelitian kualitatif tidak terlepas dari subjektivitas peneliti. Sebagai mana yang dikemukakan oleh Semiawan bahwa hasil penelitian komulitatif sangat di pengaruhi oleh pandangan,pemikiran dan pengetahuan peneliti.

Kami sebagai peneliti mangambil Metode ini dari berbagai referensi diantaranya seperti : beberapa jurnal dan pemikiran dari penulisan Alasan pemilihan keduanya adalah lebih mempermudah dan efektif dalam penerarapan efektifitas pendidikan jarak jauh pada masa pandemi, sehingga realitas yang terjadi lebih valid untuk di uji keobjektivannya mulai terkait dari teori,metode penelitian, dan bukti penunjang tertulis lainnya.

Hasil penelitian ini bisa digunakan sebagai kritik model pendidikan jarak jauh pada masa pandemi Covid 19 di indonesia dalam perspektif HAM.

\section{HASIL PENELITIAN}

Hasil penelitian ini mengungkapkan bahwa pendidikan jarak jauh di indonesia telah tidak se efektivitas. oleh karena itu dalam penelitian ini kami sebagai peneliti berharap penulisan ini bisa di implementasikan oleh pemerintah agar masyarakat khususnya para pelajar yang menerapkan metode daring atau online bisa terpenuhi dan berjalan dengan efektif sesuai Standar Operasional Prosedur (SOP).

\section{PEMBAHASAN}

\section{Pengertian Hak Asasi Manusia (HAM)}

Hak asasi manusia merupakan hak yang pasti ada di setiap individu yang mana hak tersebut tidak boleh di ganggu maupun dirampas oleh orang karena orang lain tersebut sudah memiliki haka sasi masing-nasingb makanya dalam undangundang itu dibentuk peraturan-oerayuran tentang Hak Asasi Manusia (HAM). Sudah melekat pada ha itu sendiri bahwa hak-hak asasi manusia harus difahami dan dimengerti secara universal atau umum. Menurut Soegito (2003:160), Hak asasi manusia adalah hak dasar yang melekat pada diri manusia yang sifatnya kodrati dan universal sebagai karunia tuhan yang maha esa dan berfungsi untuk menjaga kelangsungan hidup, kemerdekaan, perkembangan munusia dan msyarakat, yang tidak boleh diabaikan, dirampas dan diganggu gugat oleh siapapun. Dalam undang-undang dasar 1945 pasal 28 telah menjelaskan seacara terperinci tentang HAM yang di antaranya adalah hak untuk hidup, hak untuk berkeluarga, hak untuk berkomunikasi, dan memperoleh informasi dan hak untuk meperoleh pendidikan.

\section{Pengertian Pendidikan}

Hakikat pendidikan adalah memanusiakan manusia. Memanusiakan manusia atau proses humanisasi melihat me=abusia sebagai suatu keseluruhan didalah eksistensisnya (Tilaar, 2002: 435)

Pendidikan merupakan salah satu aspek yang penting untuk membangun pendidikan di Indonesia. Pendidiakn pada hakikatnya adalah usaha dasar untuk mengembangkan kepribadian dan kemampuan atau keahlian dalm kesatuan 
organis, harmonis dan dinamis, di dalam dan diluar sekolah dan berlangsung seumur hidup. Pendidikan adalah usaha yang terencana dalam mewujudkan suasana belajar dan proses pembelajaran atau pelatihan agar peserta didik secara efektif dapat mengembangkan potensi diri untuk diri sendiri dan lingkungannya/ masyarakat.

\section{Bentuk Penegakan HAM dilingkungan pendidikan}

Penegakan HAM dilingkungan masyarakat terutama pada lingkungan pendidikan mewajibakan bagi masyarakat untuk mengikuti pendidikan. Hal ini dapat dimiliki oleh setiap orang untuk pemenuhan hak dalam lingkungan sekitar. Untuk dapat memenuhi hak tersebut pemerintah mewajibkan memerlukan adanya pemerataan pendidikan, dalam pengertian memberikan kesempatan pada setiap orang untuk mengikuti pendidikan. Dalam hal ini, Tomasevski (2001) melihat bahwa isu pemerataan ini berkaitan dengan kewajiban pemerintah untuk bisa melaksanakan pendidikan yang memenuhi skema 4 A, yaitu available ( tersedia), accessible ( terjangkau), acceptable (diterima), dan adaptable (bisa beradaptasi). Pemerintah menyediakan sekolah-sekolah yang cukup untuk menampus seluruh anak yang akan bersekolah. penyediaan sekolah yang di buat oleh pemerintah ini akan terkait dengan adanya masalah bagi orang tua yaitu masalah dari dana, transportasi, ketersediaan guru pengajar.

Pemerintahan juga perlu menyelenggarakan pendidikan yang dapat di jangkau oleh masyarakat yang membutuhkan pendidikan. dalam segi ekonomi, kemiskinan tidak bisa dijadikan alasan seorang anak untuk tidak bisa bersekolah. karena itu , pemerintah melakukan penyelenggaraan pendidikan Gratis bagi masyarakat menengah atau kurangnya dari segi perekonomian. Hal lain yang menjadi keterkaitan dengan kejangkauan adalah masalah tempat dan waktu penyelenggaraan pndidikan. Jangan ampai anak tidak bisa untuk bersekolah karena adanya halangan jalan untuk menuju jalan akses kesekolah. Pendidikan tidak terhalang oleh diskriminasi terhadap ras, suku bangsa, agama, atau golongan yang minoritas tidak ada yang membedabedakan.

\section{A. Hak Pendidikan Warga Negara Dalam Keefektifan Pembelajaran Jarak Jauh}

Pasal 28 ayat (1) yang berbuyi : setiap orang berhak mengembangkan dari melalui pemenuhan kebutuhan dasarnya, berhak mendapat pendidikan dan memperoleh manfaat dan ilmu penegtahuan dan teknologi, seni dan budaya, demi meningkatkan kualitas hidupnya dan demi kesejahteraan umat manusia.

Disini kita warga negara Indonesia benar-benar sudah memiliki hak sejak lair salah satunya hak dalam pendidikan dan memperoleh apa yang semestinya didapatkan, tetapi ini sebaliknya dalam hal pendidikan dari $100 \%$ masih $80 \%$ warga negara Indonesia menerima pendidikan yang layak. Dulihat dari cara berfikir, kurangnya pengalaman dan tingkah lakunya dalam kehidupan seharihari.

Seharusnya pemerintah harus memperhatikan dan mengutamakan pendidikan khususnya didaerah yang jauh dari perkotaan (terpencil) dimana didaerah tersebut sistem pendidikannya sangatlah minim bagi masyarakat. Apalagi fasilitas di daerah tersebut sangatlah kurang memadai, sehingga anak-anak keseulitan dalam melakukan pembelajaran. Hal ini harus menjadi pantauan khusus dari pemerintah agar supaya terjaminya proses pembelajaran yang layak bagi masyarakat di daerah yang jauh dari perkotaan, karena tujuan utama Indonesia adalah mencerdaskan kehidupan bangsa.

Hal ini menjadikan negara Indonesia masih merupakan negara berkembang yakni bukan negara maju karena proses pendidikanya sangatlah lambat apalagi ditambah mada pasa pandemi covid-19 
sekarang yang pemerintah sendiri masih belum bisa beradapatasi dengan semua sistem pendidikan bersistem online atau daring. Masa pandemi sekarang sangatlahsulit bagi anak-anak, apalagi pada proses pembelajaran jarak jauh (daring atau online). Sehingga proses pembelajaran pada anak-anak menjadi leboh sulit lebih-leboh yang masih sekolah dasar yang belu tahu teknologi sama sekali, bukan hanya itu anak-anak harus dituntut untuk mempunyai fasilitas yang mendkung seperti smartpohine dan koata internet. Dengan adanya proses pembelajarana daring ini ada sebagia masyarakat yang tinggal di daerah yang jauh dari perkotaan (terpencil) dimana masyarakatanya sangat sulit untuk mengakses dan mendapatkan jaringan.

Bukan hanya terkendala oleh jaringan internet saja tetapi kurangnya media elektronik untuk membantu kelangsungan proses pembelajaran masih kurang efesian, untuk itu dalam hal ini sangat perlu diperhatikan oleh pemerinyah. Maka dari pemerintah harus menunjang fasilitas yang dapat membantu proses pembelajaran daring tersebut seperti menyediakan media elektronik, memberikan koata gratis selama proses pembelajaran jarak online berlangsung, dan meringankan biaya pendidikan. beberapa hal ini mungkin dapat membantu dalam proses pembelajarana dari berlangsung.

Proses pembelajaran jarak jauh atau daring ini menuntut siswa untuk belajar mandiri sendiri di rumah, dimana siswa harus benar-benar memahami palajaran yang diberikan oleh gurunya. Bukan hanya itu tugas yang diberikanpun sangatlah banyak dan menuntut para siswa untuk bisa menyelesaikan tepat pada waktunya, maka dari itu proses pembelajaran daring ini sangat membuat siswa susah memahami materi yang telah diberikan. Bukan hanya itu sistem pembelajaranpun sulit dipahami dan di cerna bagi para siswa sehingga banyak siswa yang mengeluh dan tidak faham.
Tujuan pedidikan merupakan salah satu pilar utama untuk mewujudkan masyarakat yang bermutu dan berintelektual, sebab melalui pendidikan yang baik itu lah seseorang akan lebih berintelektual. Diteguhkan keyakinan kemanusiaannya serta dibukakan akses akses terhadap sumber daya ekonomi yang mampu membawa dirinya pada kemakmuran dan kesejahteraan. Pemenuhan hak-hak atas pendidikam tersebut merupakan salah satu bagian dari penegak ham dinegeri ini.

Rumusan tujuan pendidikan disebuah negara selalu mengalami perubahan dari waktu kewaktu lebih-lebih pada massa pandemi saat ini. tujuan pendidikan pada suatu massa akan menentukan kearah mana anak didik dimasa depan. Disamping itu, bapak pendidikan Nasional Indonesia, Ki Hajar Dewantara sendiri pernah berkata "mendidik anak itulah mendidik rakat. Keadaan dalam hidup dan penghidupan kita pada zaman sekarang,itulah buah nya pendidikan yang kita terima dari orang tua pada waktu kita masih kanak-kanak."

Pada masa sebelum masuknya pengaruh hindu ke negri ini, pendidikan bagian darisistem masyarakat unruk mencapai tujuan "manusia gotong royong, manusia menghormati empuh dan mansia taat pada adat." Sedangkan pada kajayaan hindu pendidikan bertujuan untuk mencapai muksa bersatu denga siwa melalui bertapa. Setelah masuknya pengaruh budhat tujuan pendidikan tidak hanya mencapai muksa malainkan juga nirwana sepi dari kehendak. Dimasa penjajahan belanda, pemerintah hindia belanfda memberikan pendidikan dan pengajar kepada masyarakat Indonesia dengan tujuan "menyiapkan kepada kepentingan penjajah sedangkan pada masa kependudukan jepang pendidikan bertujuan untuk pembentukan militerisme dan menang dalam perang melawan sekutu."

Hak setiap warga menurut sejarah, pendidikan itu awalnya bersifat sangat eksekutif dan elistis, karena hanya di 
alami oleh golongan bangsawan saja. Para bangsawan itu selalu mengindang guruguru privat ke rumah, terutama untuk mengajarkan sastra dan filsafat sebagai suatu bentuk kelengaan (merenda kehidupan) karena mereka telah mengalami kehidupan yang mapan secara ekonomis, sehingga banyak waktu kosong yang dimiliki. Tradisi itu k41emudian berkembang dengan hadirnya filsuf yunani, pluto yang pada tahun 39 .

7 SM mengajarkan ilmu pada muridmuridnya disebuah taman bernama Academe. Nama taman ini untuk seterusnya digunakan untuk menyebut jenis bentuk pendidikan yaitu akademi. Pendidikan jasmani, music, dan satra diajarkan sampai siswa berumur 18 tahum. Setelahnya mereka diwajib kan untuk memasuki dinas militer selama dua tahun . Pada umur 20 tahun mereka kembali lagi bersekolah untuk mempelajari aritmatka, ilmu ukur, astronomi dan filsafat.

Sesuai dengan perkembangan zaman, pendidikan yang semula eksklutif dan elitis itu kemudian berkembang menjadi pendidikan untuk semua warga . Penegasan bahwa pendidikan itu menjadi hak setiap warga terdapat pada pasal 26nDeklarasi Universal HAM tahun 1948 yang menyatakan: " setiap orang berhak atas pendidikan harus bebas biaya, setidaknya pada tingkat dasar dan tingkat rendah . pendidikan harus bersifat wajib . pendidikan teknik dan profesi harus tersedia secara umu penfifikan yang lebih tinggi harus sama -sama dapat dimasuki semua orang berdasarkan kemampuan.

Deklarasi universal HAM (Hak Asasi Manusia) Tahun 1948 yang bersumber dari deklarasi - deklarasi di Eropa dan Amerika Serikat tersebut membukakan kesadaran akan terpenting nya pendidikan tersebut juga memiliki / dimiliki oleh para pendiri bangsa di Negeri ini, seperti yang tercemin seara jelas dalam rangka mencerdaskan kehidupan bangsa diatur oleh undang -undang dalam rumusan pembukaan UUD Tahun 1946 yang mengamanatkan bahwa salah satu tugas negara adalah mecerdaskan kehidupan bangsa . Pendidikan merupakan salah satu media pencerdasan bangsa yang paling efektif dan dapat berlangsung massif.

Keterbatasan pengguasaan yang menghambat dalam penggunaan teknologi kurangnya sarana dan prasarana yang memadahi, keterbatasan akses jaringan internet kurangnya penyediaan anggaran untuk memenuhi kebutuhan dalam proses pembelajaran jarak jauh.

Dari faktor tersebut proses pembelajaran secara online atau daring tidaklah efektif, karena terdapat banyak kendala-kendala yang terjadi dan akan menghambat proses pembelajaran. Banyak anak-anak merasakan kebosanan saat mengikuti proses pembelajaran daring tersebut, dan juga banyak anak-anak yang jarang mengikuti proses pembelajaran tersebut dikarenakan materi dan metode pembelajaran yang disampaikan oleh pengajar tidak bisa diterima langsung oleh anak-anak. Banyak anak-anak yang mengeluh dengan proses pembelajaran daring seperti ini dikarenakan banyak tugas-tugas yang diberikan oleh pengajar, terkendala oleh akses jaringan internet, dan banyak lagi kendalanya sehingga membuat anak-anak mengeluh dengan proses pembelajaran daring ini.

\section{B. Hubungan Pendidikan Jarak Jauh Dalam Hak Asasi Manusia Pada Masa Pandemi Di Indonesia}

Indonesia telah mengatur secara Cukup jelas tentang hak-hak asasi manusia di dalam hukum dasar negara Indonesia yaitu UUD 1945 khususnya pada amandemen kedua. Hak-hak yang di atur mencangkup pula hak-hak warga negara untuk memperoleh dan memilih pendidikan dan pengajaran yang meriupakan bagian dari kelompok hakhak politik, ekonomi sosial dan budaya

Jaminan bahwa setiap orang memiliki hak yang sama untuk memperoleh pengajaran / pendidikam juga terdapat dalam perjanjian Internasional tentang hak - hak ekonomi, sosial , budaya yakni pada 13 ayat (1) yang menyatakan bahwa 
negara- negara peserta perjanjian mengakui setiap orang akan pendidikan. meraka sepakat bahwa pendidikan hendaknya diarahkan kepada perkembangan sepenuhnya ats keperibadian manusia dan pengertian mengenai martabatnya, dan akan memperkuat penghormatan terhadap hak asasi manusia dan kebebasan yang hakiki. Merak selanjutnya sepakat bahwa pendidikan akan memungkinkan setiap orang berpartisipasi secara efektif dalam masyarakat yang bebas, meningkatkan pengertian, toleransi dan persahabatan diantara semua bangsa dan kelompok suku, etnis atau agama, dan lebih jauh kegiataan perserikatan bangsa-bangsa untuk memelihara perdamain.

Sebagai masyarakat indonesia sangat terikat dengan yang namanya peraturan hak asasi manusia (HAM) dari mulai kita lahir sampai kita mati ham tidak pernah terlepas dari jati diri kita sebagai masyarakat indonesia. Hal ini sangat melekat pada kodrat hidup sebagai warga indonesia, hak yang bukan semata-mata yang diberikan tetapi harus dilaksanakan oleh masyarakat.

Hak yang tidak memandang perbedaan antara jabatan,antara Ras, Agama dan kebudayaan semuanya sama. Maka dari itu indonesia sangat menjunjung tinggi hak asasi manusia dan masyarakatnya memiliki kewajiban dan kesempatan untuk memperolah Hak dan kewajiban masing-masing. Dalam hal ini masyarakat sangat di beri kebebasan utnuk melakukan apa saja asalkan tidak boleh melanggar semua peraturan yang telah tercantumkan dalam undang-undang pelanggaran HAM . Ham lebih di junjung tinggi dan lebih di perhatikan dalam era Revormasi dari pada era sebelumnya. Perlu di ingat bahwa dalam hal pemenuhan Hak, kita hidup tidak sendiri melainkan kita membutuhkan orang lain, dalam hal bersosialisasi dan memberikan pendapat yang bisa diterima satu pihak ke pihak yang lain. Tak hanya itu Kadang kala masyarakat memakai hak ini untuk menjadi alasan utama dalam memperoleh perlindungan.

Pada pemerintahan joko widodo dan yusuf kalla salah satu agenda prioritas adalah memperioritaskan perlindungan khususnya kepada anak, perempuan dan kelompok masyarakat termajinalkan serta penghormatan HAM dan menyelesaikan secara berkeadilan terhadap kasus-kasus pelanggaran Ham pada masa lalu menjadi momentum tepat untuk penegakkan HAM-nya.

Sangat banyak bentuk hak asasi manusia salah satunya hak untuk mendapatkan pendidikan, setiap masyarakat wajib pendidikan dari pendidikan usia dini sampai tingkat lanjut. Dalam hal ini pendidikan menjadi prioritas Utama karena tanpa pendidikan kita tidak mengetahui apa yang akan terjadi kedepannya. Akan tetapi di masa pendidikan sekarang masyarakat khususnya yang sedang menempuh pendidikan sangat sulit apalagi dimasa sekarang yang setiap pembelajarannya harus melakukan sistem pembelajaran daring. Hal ini menjadi sangat sulit untuk mendapatkan pendidikan yang optimal, Yang menjadi faktor utama dari pembelajaran ini adalah fasilitas dan jaringan internet yang mendukung.

Dalam hal ini kemandirian belajar merupakan kesiapan dari individu untuk belajar dengan inisiatif sendiri, atau tanpa adanya bantuan dari pihak lain. Berkaitan dengan hal tersebut, Sugilar (2000) merangkum pendapat Guglielmino, west, \&Bentley menyatakan bahwa karakteristik Individu yang memiliki kesiapan belajar Mandiri di cirikan Oleh : (1) kecintaan terhadap belajar (2) kepercayaan diri sebagai mahasiswa (3) keterbukaan terhadap tantanagan belajar (4) sifat ingin tau (5) pemahaman diri dalam hal belajar (6) menerima tanggung jawab untuk kegiatan belajarnya.

Dalam kemandirian ini kita sebagai penerima materi bagaimana kita hraus mempunyai inisiatif dan mempunyai pemikiran yang luas untuk mendeskripsikan apa yang kita dapat 
tanpa meminta bantuan orang lain . sehingga kita di tuntut lebih tanggung jawab pada diri kita sendiri untuk aktivitas kegiatan sehingga untuk mencapai tujuan belajar bersama.

\section{Kelebihan dan Kekurangan Penerapan Pembelajaran Jarak Jauh Pada Masa Pandemi di Indonesia}

Ditengah merebaknya wabah penyebaran covid 19, menerapkan sistem pembelajaran jarak jauh (berbasis digital atau e-learning). Pemerintah juga sudah menghimbau agar masyarakat dapat beraktivitas dirumah sebagai upaya physical distancing atau menjaga jarak untuk menekan penyebaran virus. Jadi pemerintah menerapkan sistem pembelajaran jarak jauh juga. Namun penerapan ini juga memiliki kelebihan dan kekurangan. Adapun kelebihan dan kekeuranganya adalah sebgai berikut :

1. Waktu belajar yang fleksibel

Biasanya mayoritas orang yang ingin belajar lagi tidak memiliki waktu yang cukup. Salah satu alasan nya mungkin cukup. Salah satu alasannya mungkin karena waktu yang sudah digunakan untuk bekerja. Pembelajaran jarak jauh atau digital (e-learing) ini adalah salah satu solusinya. Waktu belajar bisa dilakukan kapan saja tanpa terikat dengan jam belajar.

2. Dapat diakses dengan mudah

Diakses dengan mudah yang dimaksud ini proses pembelajaran ini bisa menggunakan smartphone, laptop atau perangkat teknologi lain yang terhubung dengan koneksi internet. Jika sudah bisa mengakses materi yang ingin dipelajari. Sistem ini dapat melakukan kegiatan dimana saja dan kapan saja.

3. Belajar dan memiliki waktu luas bersam keluarga

Menerapakan sistem belajar dirumah tentu nya banyak hal juga yang didapatkan seperti beberapa materi pelajaran yang tersedia di e-learning tidak perlu dimedia cetak seperti buku, dan punya banyak waktu luang bersama Keluarga , keluarga memang menjadi hal utama dalam kebahagiaan.

Adapun kekurangannya sebagai berikut :

1. Ketidak leluasan akses internet

Kekurangan metode pembelajaran jarak jahu adalah ketidak luasan akses internet atau terbatasnya akses internet. Seperti berada didaerah perdesaan yang tidak ada sinyal atau terkadang jaringan internet tidak stabil maka akan sulit bagi anda untuk mengakses layanan belajar online.

2. Banyaknya tugas yang diberikan

Didalam pembelajaran dirumah atau online ini. Banyak tugas yang diberikan ini bisa membuat kaget. Perubahan ritme yang biasanya tidak ada tugas jadi banyak tugas. Menjadikan tidak efektif.

3. Kurangnya interaksi dengan pengajar dan kurangnya pemahaman materi Beberapa metode pembelajaran dirumah / online bersifat satu arah. Hal tersebut menyebabkan interaksi pengajar dengan siswa berkurang sehingga sangat sulit mendapatkan pemahaman dari pemateri atau kurang jelas karena tingkat pemahaman orang berbeda-beda. Tetapi mayoritas tidak paham dengan materi yang disampaikan.

\section{KESIMPULAN}

Dari jurnal ini diharapkan agar lebih melihat bukan hanya daerah perkotaan khususnya pendidikan, tetapi pemerintah juga harus melihat daerah - derah dipedalaman karena sistem pendidikan nya sangat lah minim apa lagi pada massa sekarang yang semua nya serba online. Hal ini menjadi sangat sulit apa lagi fasilitas ( sarana dan prasaran) kurang mendukung.

\section{SARAN}

Kepada pemerintahan sebaiknya lebih teliti lagi terhadap pendidikan di khususnya daerah pedalaman yang jauh dari perkotaan, bukan hanya itu saja tapi fasilitas penunjang dari sistem pembelajaran daring harus lebih di perhatikan lagi tingkat sistem internet, 
Agar pembelajaran lebih berjalan secara maksimal dan oktimal. Jika pada sistem ini tidak di perhatikan dengan baik maka akan terjadi hal-hal yang tidak di inginkan seperti :

1. Kurangnya pengetahuan

2. Kurangnya komunikasi

3. Anak-anak lebih sering main game dari pada mengikuti pembelajaran daring

4. Anak-anak lebih menyepelekan pembelajaran, karena sistem pembelajaran membuat mereka bosan Kebanyakan dari mereka lebih memilih pembelajaran offline di bandingkan pembelajaran online, karena pembelajaran online itu lebih ketergantungan pada jaringan. Sehingga semua pembelajaran online itu terasa sia sia bagi anak anak.

\section{DAFTAR PUSTAKA}

Komisi Nasional Hak Asasi Manusia. (2020). In Wikipedia bahasa Indonesia, ensiklopedia bebas. https://id.wikipedia.org/w/index.ph p?title=Komisi_Nasional_Hak_As asi_Manusia\&oldid $=17690116$

Indriyani, D. (2018). HAK ASASI MANUSIA DALAM MEMPEROLEH PENDIDIKAN. Jurnal Pendidikan Politik, Hukum Dan Kewarganegaraan, 7(1), Article1.https://jurnal.unsur.ac.id/j pphk/article/view/392

Gunawan, B. (2020). Analisis Yuridis Pendidikan Jarak Jauh dalam Perspektif Hak Asasi Manusia dalam Undang-Undang Dasar NRI 1945 pada Masa Pandemi Covid19 di Indonesia. Jurnal HAM, 11(3),387-404.

https://doi.org/10.30641/ham.2020 $.11 .387-404$

Ulum, M. S., \& Pamungkas, J. (2020). ANALISIS

KRITIS

PENERAPAN METODE

PEMBELAJARAN BERBASIS

ONLINE DI MADRASAH IBTIDAIYAH MASA PANDEMI
COVID $19 \quad$ (SOLUSI

MENYELAMATKAN MASA

DEPAN ANAK-ANAK

INDONESIA). MUBTADI: Jurnal

Pendidikan Ibtidaiyah, 2(1), 17-

35.https://doi.org/10.19105/mubta

di.v2i1.3584

Perlindungan Hak Asasi Manusia (HAM)

di Indonesia Halaman 1-

Kompasiana.com. (n.d.). Retrieved January 27, 2021, from https://www.kompasiana.com/kezi agloria4944/5c001a8fab12ae6807 57f216/perlindungan-hak-asasimanusia-ham-di-indonesia

KI Gunawa. Memaknai Pemikiran Ki hajar Dewantara tentang pendidikan, lihat: KOMPAS, 21Juli 2003.

Soegito, dkk. 2003 Pendidikan Pancasila. Semarang: UNNESA Press.

Tilaar, H.AR.1999. Manajeman Pendidikan Nasional.

Bandung: PT. Remaja Rosdkarya.

Tahar, I. (2006). HUBUNGAN KEMANDIRIAN BELAJAR DAN HASIL BELAJAR PADA PENDIDIKAN JARAK JAUH. 7, 11.

Eko Kuntarto, (2017). Kefektifan Pembelajaran Daring Dalam Perkuliahan Bahasa Indonesia Di Perguruan Tinggi. Jurnal Indonesian Language

Education and Literature (ILEaL), ISSN (Online) Vol.3 No.1: 25022261. Di Unduh dari http://www.syekhnurjati.ac.id/jurn al/index.php/jeill/article/view/180.

Rizki Setiawan, Eti Komalasari. 2020. Membangun Efektifitas Pembelajaran Sosiologi di Tengah Pandemi Covid-19, Edusocius Jurnal Ilmiah Penelitian Pendidikan dan Sosiologi vol. 4 Nomer1, p-ISSN: 2615-1510 (Print)/e-ISSN: 2580- 2542 (online). Penegahan penyebaran corona virus disease (Covid-19), Kompasiana, Jakarta, 2020. 
